\title{
Waste Management Study In The Archipelago Tourism Area (Case Study: Nusa Penida District, Bali Province, Indonesia)
}

\author{
I Made Wahyu Widyarsanal and Elprida Agustina ${ }^{2, *}$ \\ ${ }^{1,2}$ Faculty of Civil and Environmental Engineering, Bandung Institute of Technology, Indonesia
}

\begin{abstract}
The aim of this paper is to identify patterns of waste management in the Bali archipelago tourism area. The Nusa Penida District is a new tourism destination located in the Southeast of Bali. In 2018, there were average 391,071 tourists/day coming and 45,520 local residents live in this area. The total amount of waste produced in Nusa Penida District is 15.90 tonnes/day or $173.61 \mathrm{~m} 3 /$ day. High tourist activities have not been handled by a good waste management. Questionnaires were distributed randomly to the public and tourists to find out the pattern of waste management. Observation also conducted to build the material flow analysis as a waste information baseline. Around $48.21 \%$ organic waste used as livestock feed and $8.45 \%$ dumped carelessly to the environment. Around $32.51 \%$ anorganic waste be burnt and $45.68 \%$ waste dumped carelessly. Moreover, Nusa Penida District facing offering waste management problem caused by their cultural activities. In total, around 8.82 tonnes/day waste is dumped in landfills and total unmanaged waste around 6.73 tonnes/day.
\end{abstract}

\section{Introduction}

Waste management is one of the challenges of governments in developing countries, especially due to increased waste generation and lack of appropriate waste management standards understanding [1]. Nonenvironmental friendly waste management can cause a negative impact on health and will disrupt environmental sustainability [2]. In a tourism region, waste problem will also have a negative impact due to environmental degradation [3].

Tourism is the most dynamic economic activity and can be the main income that benefits a region [4]. All human activities both from tourism activities and local residents will produce waste. Population growth and increased human activity further leads to an increase of waste generation. Good management should be done as soon as possible, also for Nusa Penida District in Indonesia. Nusa Penida District is an island tourism area that is being internationally discussed. Nusa Penida District is being intensively built by district and provincial governments to increase tourist attractions. Increased activity that results in an increase of waste generation.

Besides bringing economic benefits to the island, the tourists also bring negative impacts to the island, again, without a good handling by the government. Problems caused by waste can be multiplied because in addition to local waste source, the island must also manage waste from tourists whose numbers are uncertain, can be little or a lot. Because of the waste is not possible to be transported back to the place of origin of tourists, the islands must provide a good management system for all the waste produced by the tourism activities [5].

The existing waste management system is very limited and not all of it can be applied on a small island. Moreover, management must consider the convenience of tourists so that regional income does not decrease [6]. If island does not has a good management system, with all the total waste generated by both local residents and visiting tourists, the island can harm the land and water bodies, also spread disease vectors.

Unlike the rural and border areas, the main problem of waste management in small islands is limited land and making it difficult to carry out waste management infrastructure such as Material Recovery Facility or landfill development [7]. Waste management on small islands, requires a lot of separate costs. For example, the cost of waste management in Rarotonga, Cook Island, is estimated to require a fee of $3 \%$ of regional income [8]. The problem is that not all islands have good funding capabilities, except if the island is advanced in the tourism sector. But this certainly becomes complicated for most small islands in Indonesia which only rely on limited regional financing in managing their waste.

* Corresponding author: elpridaagustina@gmail.com 
Unfortunately in Nusa Penida District, the increasing of waste generation is not accomodated by a good waste management. Existing management activities are carried out with collecting, transporting, and final dumping in 2 landfills. In 2018, Nusa Penida was discussed throughout the world because of the floating plastics waste in the diving area. The source of the waste cannot be ascertained, whether it was brought from another island due to the west or east monsoon winds. For every reason, Nusa Penida District needs to maintain the sustainable tourism areas with the sustainable waste management by [5]:

- Increasing implementation of environmental laws

- Reducing the ecological impact

- Applied financial improvements

- Improved application of technology used

This paper will discuss waste management patterns related to solid waste baseline data, existing conditions of management, as well as social threats to waste management to ensure good waste management in the future.

\section{Background}

Nusa Penida District is the largest district compared to 4 (four) other districts in Klungkung Region. The total area of Nusa Penida is $202.84 \mathrm{~km} 2$ and covers two-thirds of the Klungkung District total area. Nusa Penida District consists of 3 (three) islands, they are Nusa Penida Island, Nusa Lembongan Island, and Nusa Ceningan Island. The main resident occupation in Nusa Penida District is tourism services and fishermen. Nusa Penida District is located in the southeast of Bali Island. The geographical boundaries of Nusa Penida District as follows:

- North and west boundary: Badung Strait

- Eastern boundary: Lombok Strait

- Southern boundary: Indonesian Ocean

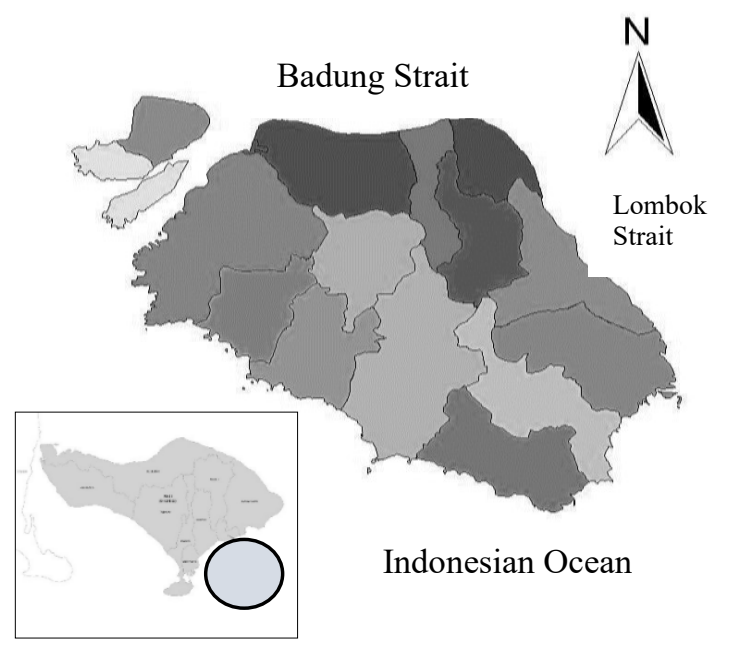

Figure 1. Location of Nusa Penida Island
There are around 40 tourist destinations in this archipelago, among which the most famous are Crystal Bay, Broken Beach, and Kelingking Beach. Tourism activities are concentrated on the island of Nusa Lembongan. There has been waste management by DLH (Environmental Agency) of Klungkung Regency in 2 (two) islands, namely Nusa Penida Island and Nusa Lembongan. The percentage of services on the islands of Nusa Penida and Nusa Lembongan is around 40\%. Unlike the two islands, Nusa Ceningan Island has not been able to be served at all due to limited land and lack of access. Nusa Lembongan and Nusa Ceningan are connected only by a small bridge, called Yellow Bridge, which is only 2 meters wide.

The waste transported by a door-to-door transportation and transported directly to the landfill, namely Biaung Landfill (Nusa Penida Island) and Jungut Batu Landfill (Nusa Lembongan Island). Waste in the tourism area is piled up and then burned by restaurant or hotel managers around that area. In accordance with the risk index analysis, it is known that the status of the Jungut Batu TPA and the Biaung TPA are in the moderate dangerous status. This means that rehabilitation is required for the two landfills and also for additional waste handling in addition to minimize the direct disposal to the landfill.

\section{Methods}

Various activities are carried out to collect data in this study such as primary data collection and secondary data. The primary data collection is done by sampling waste generation directly, while secondary data collection is done to the relevant institutions to determine the waste management system as well as the handling waste in Nusa Penida Sub-District.

\subsection{Observations}

The survey was conducted on April 2018 and November 2018. The purpose of this field survey was to obtain data on the existing conditions of waste management in Nusa Penida Sub-District and determine the opportunity and thread for an appropriate management. Observations were also made to investigate the material flow of waste in the Nusa Penida islands. Illegal disposal points are plotted on the map to find out the areas with the highest risk of illegal waste disposal and can be used as a basis for future system improvement.

\subsection{Interview}

Interview were conducted with stakeholders related to the waste sector, namely the UPTD DLH (Environmental Services Task Force Implementing Unit) of Klungkung Regency, Nusa Penida District, and the management of the Waste Bank on Nusa Lembongan Island. Interview also conducted with 50 local residents and also 20 the tourists to find out the patterns of community waste management and their opinions on existing management. 


\subsection{Measurement of Waste Generation and Composition}

Determination of the number of respondents

The number of people taken as samples for residential waste follows the Indonesian national standard (SNI M 36-1991-03) equation.

$$
S=C d \sqrt{P_{S}}
$$

Where:

$\mathrm{S}=$ number of respondents (people)

Ps $=$ population (people)

$\mathrm{Cd}=$ domestic coefficient; a value of 0.5 area with a small density region

Nusa Penida is a tourism area with 45,553 local residents. Assuming the number of lives in one family is 5 people, so there are 9,120 families as the population. Based on this number, the number of samples needed to represent the Nusa Penida District will be calculated. With a $\mathrm{Cd}$ of 0.5 , which is a medium density area (population $<500,000$ ), a sample size is calculated to represent a population of:

$$
\begin{gathered}
n=0.5 \times \sqrt{9,120} \\
n=48
\end{gathered}
$$

Sampling of 48 families was carried out using the Stratified Random Sampling method. In addition, 50 public facilities were determined to be sampled to represent all public facilities in Nusa Penida District, including schools, shops, clinics, offices, and roads. Samples were also taken to determine the contribution of waste generation due to tourism activities such as hotels, restaurants, tourist attractions, and temples.

\section{Calculation of waste generation and waste composition}

Waste generation is calculated by accumulating all waste from all analyzed sources of waste. The source consists of waste from local residents' activities and also tourist activities that are accommodated by public facilities in Nusa Penida District. Waste composition is calculated by sorting waste into 10 types and weight of each type compared to total weight. The composition of the waste is food waste, wood and garden waste, paper, textiles, rubber, leather, plastic, metal, glass, and hazardous waste.

\section{Results \\ Basic Waste Data \\ Waste Generation and Composition}

Waste generation sampling in Nusa Penida District was conducted on 3 islands by dividing it according to income level with random sample. The waste generation results on each island can be seen in Table 1 below.

Table 1. Waste generation

\begin{tabular}{lrrrrrrr}
\hline \multirow{1}{*}{ Island } & Population & \multicolumn{2}{c}{ Volume } & Weight & \multicolumn{2}{c}{ Non Domestic } & \multicolumn{2}{c}{ Total } \\
& & Volume & Weight & Volume & Weight \\
(m3/day) & (ton/day) & (m3/day) & (ton/day) & (m3/day) & (ton/day) \\
\hline Nusa Penida & 38421 & 82.99 & 8.50 & 54.10 & 3.16 & 137.09 & 11.65 \\
Nusa Lembongan & 5163 & 17.75 & 2.36 & 7.73 & 0.66 & 25.48 & 3.02 \\
Nusa Ceningan & 1992 & 7.18 & 0.90 & 3.87 & 0.32 & 11.04 & 1.22 \\
& & TOTAL & & & & 173.61 & 15.90 \\
\hline
\end{tabular}

Besides the houses sampling, there are also waste sampling at public facilities on 3 islands, involves market, store, restaurants, offices, schools, community health center, temples, local roads, and tourist attractions.

Contribution of waste generation to accommodate tourist activities is $26.03 \%$ by weight or $37.8 \%$ by volume. Addition of about 4.14 tons / day or $65.7 \mathrm{~m} 3$ / day of waste is a large amount to be accommodated by a small island. Then in Table 2, it can be seen that the number of solid waste generation at the source is in health facilities as well as in restaurants. Tourism activities center on restaurants and lodging.

In addition to waste generation data, data on the composition of waste in each island is also obtained. The composition of waste in each island as can be seen in Table 2. The significant composition of waste is food waste. On the island of Nusa Penida the amount of food waste is far more than the other 2 islands. This can be caused by the high culinary activities in the Nusa Penida region. On other islands, the composition of waste is dominated by wood waste and garden residues.

Table 2. Waste Composition

\begin{tabular}{llrrr}
\hline \multirow{2}{*}{ No } & \multirow{2}{*}{ Item } & \multicolumn{3}{c}{ \%Wet Weight } \\
\cline { 3 - 5 } & & NP & \multicolumn{1}{c}{ NL } & \multicolumn{1}{c}{ NC } \\
\hline 1 & Food waste & 61.6 & 36.40 & 39.5 \\
2 & Wood and garden waste & 24.2 & 44.62 & 33.1 \\
3 & Paper Waste & 4.3 & 7.01 & 8.6 \\
4 & Textile & 2.4 & 2.26 & 6.0 \\
5 & Rubber and leather & 0.5 & 0.27 & 0.2 \\
6 & Plastic & 4.3 & 6.07 & 7.4 \\
7 & Metal & 1.8 & 0.93 & 1.3 \\
8 & Glass & 0.4 & 1.75 & 0.1 \\
9 & Hazardous Waste & 0.5 & 0.24 & 1.3 \\
10 & Others & 0 & 0.46 & 2.43 \\
& Total & 100 & 100 & 100 \\
\hline
\end{tabular}

Information:

- NP = Nusa Penida,

- NL = Nusa Lembongan Island

- $\mathrm{NC}=$ Nusa Ceningan Island 


\section{Questionnaire Data}

\section{Questionnaire for Local Residents}

The role of the community in waste management can be done through various ways such as building local communities engaged inw waste reduction and recyling [9]. Therefore, it is important to know how the community willingness to participate [10]. Questionnaire was conducted using the stratified random sampling method. Respondents who then represented the population in the Nusa Penida region of $66.67 \%$ had a fairly high economic level with an income of $>$ IDR 5 million. The occupation of the head of household from the sample that dominated was fishermen and also worked in the tourism sector such as owning lodging, renting fast boats, and also working in restaurants.

Organic and inorganic waste hadling needs to be determined to control. Around $11.07 \%$ was burned in front of residents' homes, $8.45 \%$ of respondents dispose of their organic waste in an open environment, both water bodies and empty land. In addition, $32.27 \%$ was burried and around $48.21 \%$ used as a livestock feed. Organic waste handling as can be seen in Fig 2.

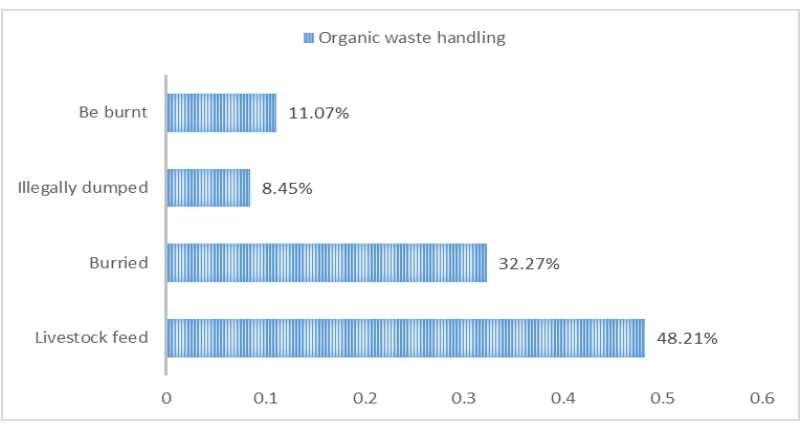

Figure 2. Organic waste handling

In addition, anorganic waste handling at the source is also inventoried. As much as $6.26 \%$ of inorganic waste sold either to formal or informal recycling centre, that means residents are willing to manage their inorganic waste to be properly contained and separated. Around $32.51 \%$ of inorganic waste is burned in front of his house carelessly, around $45.68 \%$ illegally dumped to the environment, and around $15.55 \%$ been burried. Anorganic waste handling as can be seen in Fig 3.

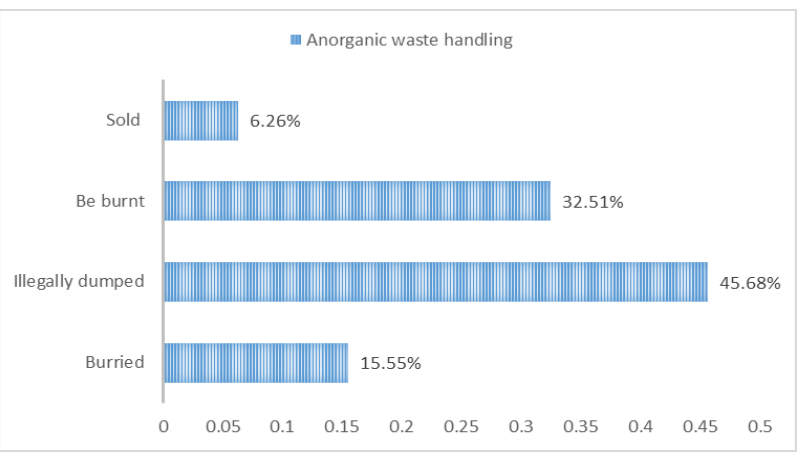

Figure 3. Anorganic waste handling
While observing, plotting was also carried out on illegal dumping points both in water bodies and in open fields. As can be seen in Figure 4, the green dot is an illegal dump site. Observed further, the location of illegal waste disposal is the point where tourism activities occur. Waste disposal is also quite a lot happening on Nusa Lembongan Island though, where this area is a concentration of tourist activity from foreign countries.
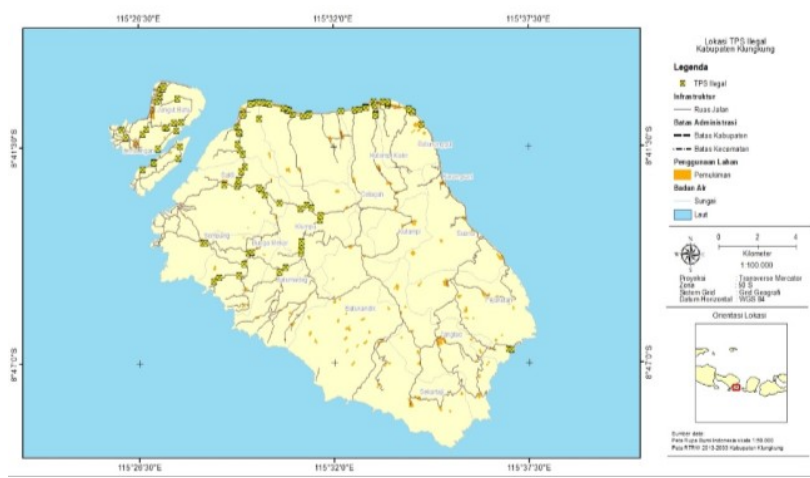

Figure 4. Illegal dumping plotting

Respondents were also asked about their satisfaction with waste management at this time. According to $40 \%$ of the residents, solid waste management is good, while $33 \%$ of residents say that waste management is still ineffective, and the remaining $27 \%$ of residents say that existing waste management is sufficient to accommodate the waste it produces.

\section{Questionnaire to the Tourists}

$70 \%$ of respondents said that the cleanliness conditions on the islands in Nusa Penida District were in good condition. While Figure 6 is a tourist response to the question if the condition of Nusa Penida's cleanliness is declining whether it will affect the desire of tourists to return again. As many as $80 \%$ of tourists stated that cleanliness largely determines their desire to return to the Nusa Penida District.

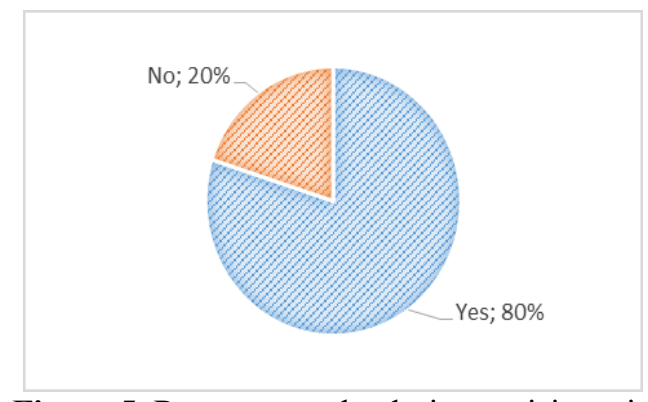

Figure 5. Response to the desire to visit again

\section{Social Aspect}

Tri Hita Karana is a Balinese traditional philosophy for life. The literal translation is roughly the "three causes of well-being" or "three reasons for prosperity". They still hold this Tri Hita Karana but they also realize that there are limitations due to significanlty increased tourism activity since 2016 . 
Balinese culture that impact the waste generation:

- Daily offerings in front of their buildings for 2 offerings per day made from Coconut Leaves

-Offering for the feast day (Galungan Day, Kuningan Day, Nyepi Day, Full Moon Night, etc)

-Offering for Nganyut, ceremony after Ngaben (Balinese's Hindu funerals by cremation) by release offerings and the cremated ashes to river/sea

The local government has realized the huge quantity waste caused by the offerings. Government and religious experts are discussing alternatives by replacing the material or waste management system so as not to reduce the meaning of the culture. Percentage of offering waste that dumped into the landfill based on their sources as can be seen in Fig. 6.

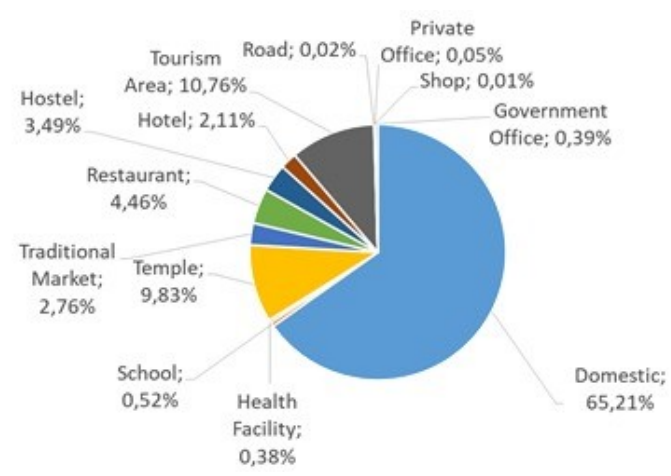

Fig 6. Offering waste based on the source

\section{Waste Material Flow}

After obtaining information about waste management, a material flow management on existing waste is conducted. Waste material flow used to determine the waste flow in the whole of the wsate management chain also the actors. Waste in the source The waste management consists of sources of waste, removal at the TPS, reduction by the informal sector, final processing, and the sale of waste reduction results outside of Nusa Penida Island. The material flow of waste management can be seen in Figure 7 .

In the material flow analysis in Figure 7, it can be seen that most of the waste, which is $55.14 \%$, is processed in landfills with inadequate operations and facilities. The remaining $42.08 \%$ of waste is disposed of improperly. Around $2.78 \%$ can be reduced and sold to large collectors outside Nusa Penida District. Most of the waste that has economic value and is sold the most is plastic waste with certain types of PET and PP.

Various activities to support community information about waste management in small islands, namely counseling, training, and cleaning programs also need to be carried out. Educating the community will reduce the risk of environmental damage such as forest fires and soil pollution. In addition, legal and institutional strengthening is needed to reduce the practice of littering to the environment.

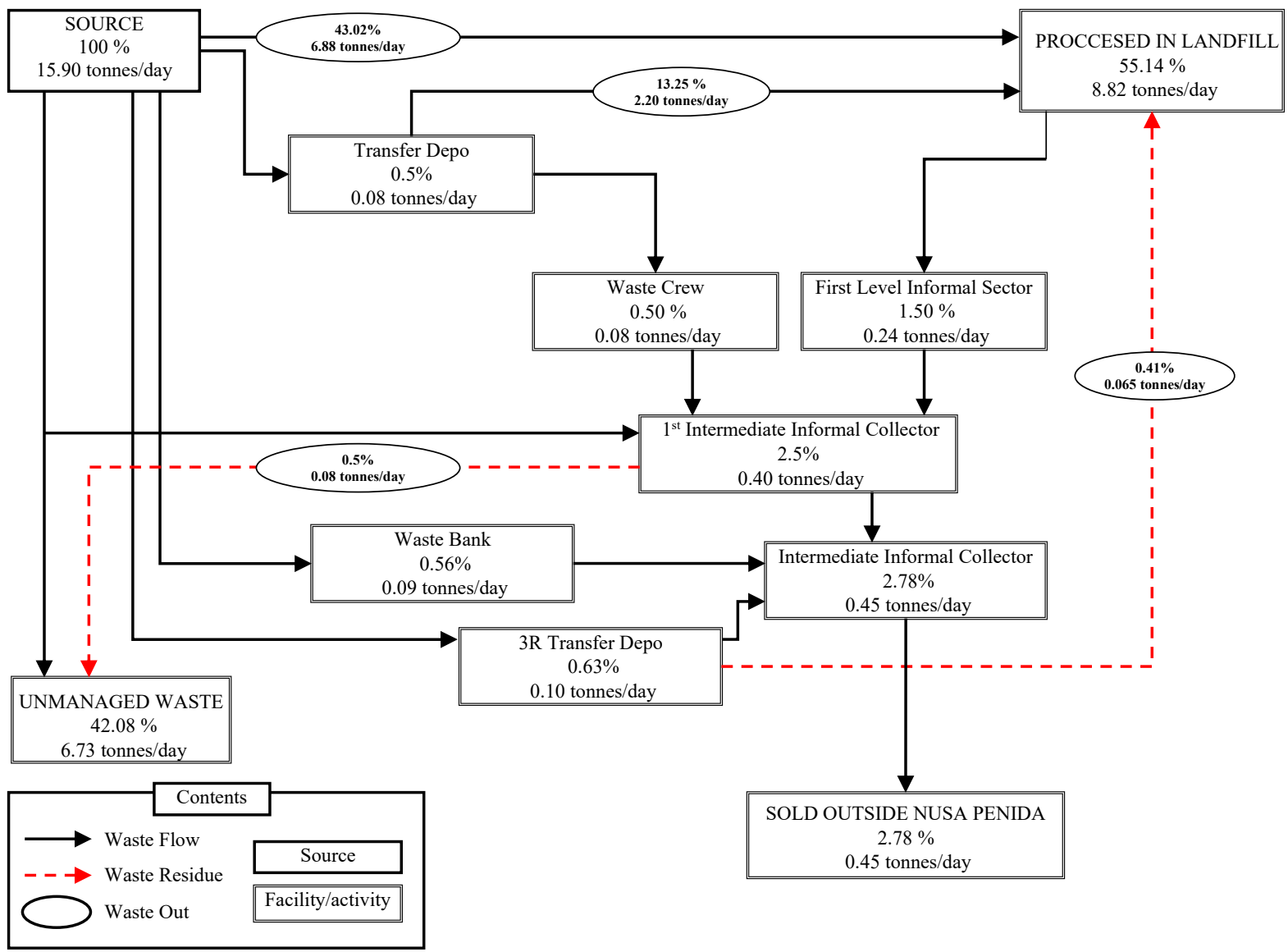

Figure 7. Material flow in Nusa Penida District 
On the other hand, waste from an economic perspective can be a resource whose economic value can be restored. The main key to recovering economic value is by sorting and processing. In accordance with Law No. 18 of 2008, waste management must be followed by handling and reduction. With processing the indirect handling and reduction has been carried out. In accordance with government directives with Universal Access 2019, 50\% of the waste goes to the 3R facility and $20 \%$ of the residue is transported to the landfill. Thus $70 \%$ of the waste is transported to the landfill site. However, these figures were considered unrealistic, and then a more realistic policy was established, namely the National Strategy for 2025 (National Policy and Strategy for Waste Management 2025). According to Jaktranas 2025, $30 \%$ of the waste goes to the $3 \mathrm{R}$ facility and $10 \%$ of the residue is transported to the landfill. So that $80 \%$ of the waste is transported to the landfill. Thus the waste management in Nusa Penida District will be more sustainable and also provide a greater benefit value.

\section{Conclusion}

Waste management in Nusa Penida district is still in poor condition. The practice of illegal disposal into water bodies and empty land is a challenge for managers to be able to stop it and start more sustainable waste management. $55.14 \%$, is processed in landfills with inadequate operations and facilities. The remaining $42.08 \%$ of waste is disposed of improperly. Around $2.78 \%$ can be reduced and sold to large collectors outside Nusa Penida District. The reduction in waste is very minimal compared to the amount of waste produced. Thus in the future waste management in the Nusa Penida area, as one of the best tourist areas in Indonesia, can be implemented well.

\section{Acknowlegment}

This research was funded from the Research Program, Community Service and Innovation (P3MI) ITB Expertise Group in 2018.

\section{References}

[1] Guerrero, L. A., Maas, G., Hogland, W. (2013): Solid waste management challenges for cities in developing countries, Waste Management, 33(1), 220-232.

[2] Marshall, R. E., Farahbakhsh, K. (2013). Systems approaches to integrated solid waste management in developing countries, Waste Management, 33(4), 988-1003.

[3] Henry, R. K., Yongsheng, Z., Jun, D. (2006): Municipal solid waste management challenges in developing countries - Kenyan case study, Waste Management, 26, 92-100.

[4] Shamshiry, E., Nadi, B., Bin Mokhtar, M., Komoo, I., Hashim, H.S., Yahaya, N. 2011. Integrated
Models for Solid Waste Management in Tourism Regions: Langkawi Island, Malaysia. Journal of Environmental dan Public Health vol. 2011 Article ID 709549, 5 pages.

[5] Davenport, John dan Davenport, Julia L. 2006. The Impact of Tourism dan Personal Leisure Transport on Coastal Environments: a Review Estuarine, Coastal, and Shelf Science 67, 280-292.

[6] Chen, M.C., Ruijs, A., Wesseler, J. 2005. Solid Waste Management on Small Island: The Case of Green Island, Taiwan. Resources, Concervation, dan Recycling 45, 31-47.

[7] Mimura, N., L. Nurse, R.F. McLean, J.Agard, L. Briguglio, P.Lefale, R.Payet dan G.Sem. 2007. Small Island Climate Change 2007: Impacts, Adaptation, and Vurneability. Contribution of Working Group II to the Fourth Assessment Report of the Intergovermental Panel on Climate Change, M.L.Parry, Eds., Cambridge University Press, Cambridge, UK, 687-716.

[8] Skordilis, A. (2004) Modelling of Integrated Solid Waste Management Systems in an Island. Resources, Conservation and Recycling, 41, 243 254. http://dx.doi.org/10.1016/j.resconrec.2003.10.007

[9] Macrae, G., Rodic, L. (2015): The Weak Link inWaste Management in Tropical Asia? Solid Waste Collection in Bali. Habitat International 50 (2015) 310-316, Elsevier.

[10] Warmadewanthi, I. D. A. A., Kurniawati, S. (2018). The Potential of Household Solid Waste Reduction in Sukomanunggal District, Surabaya. The 4th Int. Seminar on Sustainable Urban Development, IOP Publishing. 